\title{
Kebijakan model palliative care untuk menurunkan nyeri pada ODHA
}

\author{
Ummu Muntamah ${ }^{1}$, Siti Haryani ${ }^{2}$ \\ ${ }^{1,2}$ Fakultas Keperawatan, Universitas Ngudi Waluyo, Indonesia \\ *Coresponding Author: nyfaizza@yahoo.com
}

\begin{abstract}
Abstrak
Pendahuluan: Tingginya angka ODHA memerlukan perhatian khusus karena dampak negatif pada kondisi fisik maupun psikis. Sebagian besar pasien berobat pada stadium lanjut dengan berbagai infeksi oportunistik (IO), sehingga diperlukan pengobatan suportif untuk meningkatkan kualitas hidup pasien melalui palliative care. Tujuan penelitian ini, yaitu membangun kebijakan model palliative care sebagai upaya meningkatkan kualitas Hidup pada ODHA. Metode: penelitian ini menggunakan metode action research dengan jumlah sampel 88 perawat. Hasil: analisa menggunakan uji rank Wilcoxon diperoleh nilai Z hitung $=-5,599$ dengan $p$ value $0,000<\alpha=0,05$, artinya terdapat perbedaan yang signifikan tingkat pengetahuan perawat sebelum dan setelah diberikan modul dan pelatihan palliative care untuk mengatasi nyeri pada ODHA. Simpulan: ada pengaruh pelatihan dan modul palliative care terhadap tingkat pengetahuan perawat. Nilai rerata tingkat pengetahuan perawat tentang palliative care setelah dilakukan pelatihan lebih besar dari pada sebelum pelatihan $(22,88)>19,28)$. Hasil ini menunjukkan adanya peningkatan pengetahuan perawat tentang palliative care.
\end{abstract}

Kata kunci: ODHA; nyeri; palliative care; kualitas hidup

\section{Palliative care model policies to reduced pain in PLWHA}

\begin{abstract}
Introduction: High rates of PLWHA require special attention because of the negative impact on physical and psychological conditions. Most patients seek treatment at an advanced stage with various opportunistic infections (Ols), so supportive treatment is needed to improve the quality of life of patients through palliative care. This study was to develop a palliative care model as an effort to improve the quality of life of PLWHA. Methods: this research uses action research method with a sample of 88 nurses. Results: The analysis used the Wilcoxon rank test obtained $Z$ count $=-5,599$ with $p$ value $0,000<\alpha=0.05$, meaning that there are significant differences in the level of knowledge of nurses before and after being given modules and training in palliative care to overcome pain in PLWHA. Conclusions: There was an effect of training and palliative care modules on the level of knowledge of nurses. The mean value of nurses' knowledge about palliative care after training is greater than before training (22.88)> 19.28). These results indicate an increase in nurses' knowledge about palliative care.
\end{abstract}

Keywords: PLWHA; pain; palliative care; quality of life

How to Cite: Muntamah, U., \& Haryani, S. (2019). Kebijakan model palliative care untuk menurunkan nyeri pada ODHA. NURSCOPE: Jurnal Penelitian dan Pemikiran Ilmiah Keperawatan, 5(2), 38-45

\section{PENDAHULUAN}

HIV/AIDS merupakan tantangan terbesar dalam mencapai target MDGs. Penularan infeksi baru HIV masih terjadi dan pengidap AIDS masih ditemukan, dalam hal ini upaya pencegahan dan deteksi dini HIV harus terus digalakkan. Sejak pertama kali ditemukan tahun 1987 hingga Desember 2013, secara kumulatif jumlah penderita HIV mencapai 127,416 orang dan AIDS berjumlah 52,384 (Ditjen PP dan PL Kemenkes RI 2014). Saat ini di dunia terdapat 39,4 juta orang yang hidup dengan HIV/AIDS, dan diperkirakan separuhnya adalah perempuan. Pada 2009, penderita HIV sebanyak 9.793 orang dan AIDS sebanyak 5.483 orang. Sedangkan pada 2013, penderita HIV sebanyak 10.362 orang dan AIDS sebanyak 4.943 (Kebijakan Indonesia, 2013). 
Angka tersebut di atas bukanlah angka yang kecil, sangat memerlukan perhatian khusus dalam menangani kasus ini karena dampak negatif yang diakibatkan oleh penyakit inipun sangat berbahaya pada kondisi fisik maupun psikis. Sebagian besar pasien diberobat pada stadium lanjut dengan berbagai infeksi oportunistik (IO), dan keadaan umum jelek. Sebagian besar pasien juga mempunyai masalah sosial seperti kemiskinan, pengangguran, masalah keluarga, masalah psikologis seperti ketergantungan obat, depresi. Oleh karena itu, diperlukan suatu pengobatan suportif yang bertujuan memperbaiki kualitas hidup pasien dan meringankan penderitaan, disebut palliative care. Palliative care diberikan sebagai suplemen dan aditif dari terapi kausal ARV, dan terapi IO.

Palliative care merupakan perawatan untuk mencegah, memperbaiki, mengurangi gejala-gejala suatu penyakit, namun bukan berupaya penyembuhan. Palliative care menggunakan pendekatan untuk memperbaiki kualitas hidup pasien dan keluarganya dalam menghadapi penyakit yang mengancam jiwa, melalui pencegahan, penilaian, pengobatan nyeri dan masalah- masalah fisik lain, juga masalah psikologis dan spiritual lainnya. Suatu perawatan yang bertujuan mencapai kwalitas hidup optimal bagi ODHA dan keluarganya, dengan meminimalkan penderitaan dengan perawatan klinis, psikologis, spiritual, dan sosial sepanjang seluruh perjalanan penyakit HIV ( HIV/AIDS palliative care guideance. US Dept. of State, 2006).

Salah satu jenis palliative care dalam hal ini adalah manajemen nyeri pada ODHA. Hal ini disebabkan keluhan yang dirasakan pada ODHA di antaranya adalah nyeri. Nyeri yang dialami pada ODHA diantaranya nyeri tenggorokan, nyeri kulit, nyeri pada dada dan lain-lain. Hal ini disebabkan adanya proses infeksi oportunistik pada ODHA. Pengendalian nyeri oleh perawat bisa dilakukan melalui latihan bagi petugas medis dan pemberi pelayanan lainnya untuk penanganan nyeri. Selain itu, juga dapat dengan melakukan advokasi untuk melonggarkan sistim hukum yang memungkinkan tersedianya obat penghilang nyeri,namun pada praktek yang ada di pelayanan kesehatan masih banyak hambatan. Hal ini disebabkan sumber daya yang terbatas. Sehingga pelayanan paliatif belum mendapat perhatian khusus, umumnya hanya dilakukan oleh perawat saja. Sulit membentuk tim, karena keterbatasan SDM. Selain itu, faktor kerahasiaan membatasi upaya perawatan paliatif di rumah oleh anggota keluarganya. Sehingga yang sering terjadi perawatan paliatif masih diberikan pada menjelang ajal saja. Melihat latar belakang tersebut peneliti ingin meneliti tentang "Membangun Kebijakan Model Palliative care Sebagai Upaya Meningkatkan kualitas Hidup Pada ODHA".

\section{METODE}

Sejalan dengan tujuan yang ingin dicapai dalam penelitian ini, yaitu Membangun Kebijakan Model Palliative care Sebagai Upaya Meningkatkan kualitas Hidup Pada ODHA maka penelitian ini menggunakan metode action research. Metode ini dipilih karena pada tahap pertama akan dilakukan kajian (research) terhadap kondisi dan tingkat pengetahuan perawat tentang palliative care serta penyusunan modul SOP palliative care sehingga dapat menjadi panduan petugs kesehatan untuk melakukan palliative care. Kemudian pada tahap kedua akan dilaksanakan implementasi/tindakan (action) untuk menerapkan serta menguji penerapan dan efektifitas modul SOP paliative care yang diberikan pada perawat. Secara keseluruhan kegiatan penelitian akan diselesaikan dalam dua tahap, dengan rincian kegiatan pada masing-masing tahap sebagai berikut:

\section{Tahap Pertama:}

Tujuan yang ingin dicapai dari pelaksanaan kegiatan pada tahap pertama adalah untuk menghasilkan satu pengetahuan tentang palliative care yang dapat dipergunakan untuk memberikan pemahaman yang baik dan benar tentang palliative care pada ODHA. Untuk mewujudkan tujuan tersebut maka kegiatan utama akan dilaksanakan dalam dua langkah yakni: (1) melakukan analisis terhadap kondisi dan tingkat pemahaman tentang palliative care pada ODHA, dan (2) melakukan analisis terhadap faktor-faktor yang memperngaruhi perawat dalam melakukan palliative care pada ODHA. 
Metode yang digunakan untuk mengumpulkan data primer adalah metode survei dengan menggunakan kuesioner terstruktur. Sebelum dilakukan survei, dilaksanakan kegiatan penyusunan kuesioner dan pra-survei untuk pemantapan kuesioner. Sesudah kuesioner disempurnakan, kemudian dilakukan kegiatan pengumpulan data primer dengan metode survei pada beberapa wilayah terpilih yang merupakan rumah sakit/puskesmas di Kab. Semarang. Perolehan data primer dilakukan melalui pengamatan langsung ke lapangan dan wawancara dengan responden. Data yang diperoleh kemudian dianalisis dengan metode descriptive analysis dan simple regression analysis menggunakan program SPSS (Statistical Packages for Social Sciences).

\section{Tahap Kedua:}

Tahap kedua ditujukan untuk mengimplemantasikan pra modul Palliative care pada ODHA di pelayanan kesehatan. Kegiatan pada tahap kedua ini akan dilaksanakan dalam dua langkah meliputi: (1) mengembangkan pra- modul Palliative care pada ODHA di pelayanan kesehatan, dan (2) menguji penerapan dan efektifitas pemanfaatannya di pelayanan kesehatan. Langkah pertama akan dimulai dengan sosialisasi model, persiapan dan implementasi model. Setelah model diaplikasikan, kemudian akan dilaksanakan langkah kedua yakni verifikasi model dan penyempurnaan model. Kegiatan tahap kedua ini akan menghasilkan modul Palliative care pada ODHA di pelayanan kesehatan untuk meningkatkan kualitas hidup pada ODHA.

Target populasi dalam penelitian ini adalah perawat di Kabupaten Semarang. Peneliti menerapkan teknik convenience sampling. Kriteria Inklusi yang digunakan dalam penelitian ini adalah perawat yang dinas di Rumah Sakit/Puskesmas Kab. Semarang, usia $\geq 30-50$ tahun, bertugas merawat pasien dengan ODHA dan mempunyai pengalaman kerja merawat ODHA lebih dari 5 tahun. Adapun kriteria ekslusi dalam penelitian ini adalah, perawat yang tidak merawat ODHA karena a $\mathrm{k}$ a $\mathrm{n}$ berpengaruh pada kemampuan kognitifnya dalam menjawab pertanyaan yang dalam kuesioner. Jumlah perawat yang ada di kabupaten Semarang 724 perawat (Profil Dinas Kesehatan kab. Semarang 2015), sehingga jumlah sampel dengan menggunakan rumus slovin dengan kesalahan pengambilan sampel yang dapat ditolerir (nilai e $=10 \%$ ) adalah : 88 perawat.

\section{HASIL DAN PEMBAHASAN}

Diagram 1 menunjukkan bahwa karakteristik responden berdasarkan jenis kelamin sebagian besar responden berjenis kelamin laki-laki $=55 \%$, sedang perempuan $=45 \%$. Pada diagram 2 menunjukkan karakteristik responden berdasarkan usia sebagian besar responden responden berusia lebih dari 40-50 tahun (60\%). Sedang yang berusia 30-40 tahun sebanyak 40\%. Sedangkan pada diagram 3 menunjukkan karakteristik responden berdasarkan tempat kerja yaitu sebagian besar $66 \%$ responden bekerja di Puskesmas dan yang bekerja di Rumah Sakit sebesar 34\%. Pada diagram 4 menunjukkan karakteristik responden berdasarkan tempat kerja sebagian besar responden telah merawat pasien $\mathrm{ODHA}>15-20$ tahun (31\%) dan yang paling rendah adalah lama kerja $>10-15$ tahun $15 \%$.

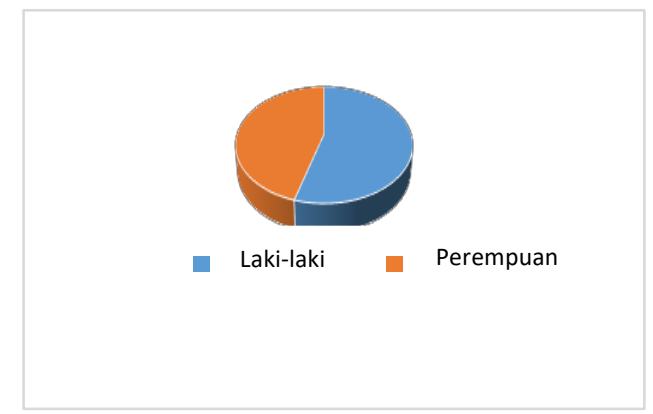

Diagram 1. Karakteristik responden berdasarkan jenis kelamin 
Karakteristik responden berdasarkan usia

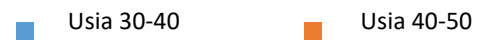

\section{Diagram 2. Karakteristik responden berdasarkan usia}

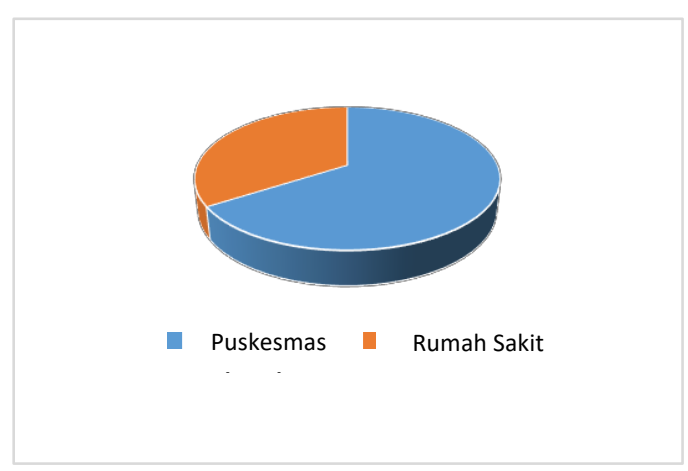

Diagram 3. Karakteristik responden berdasarkan tempat kerja



Diagram 4. Karakteristik responden berdasarkan lama kerja

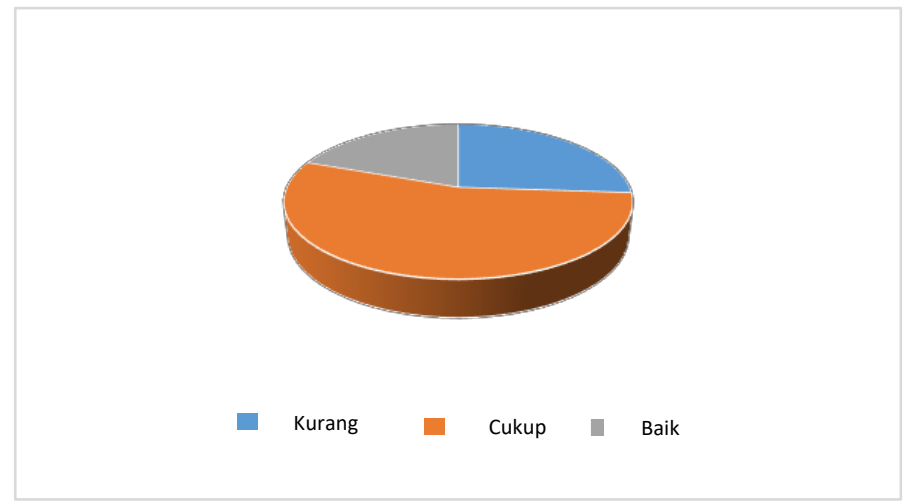

Diagram 5. Karakteristik responden berdasarkan tingkat pendidikan 


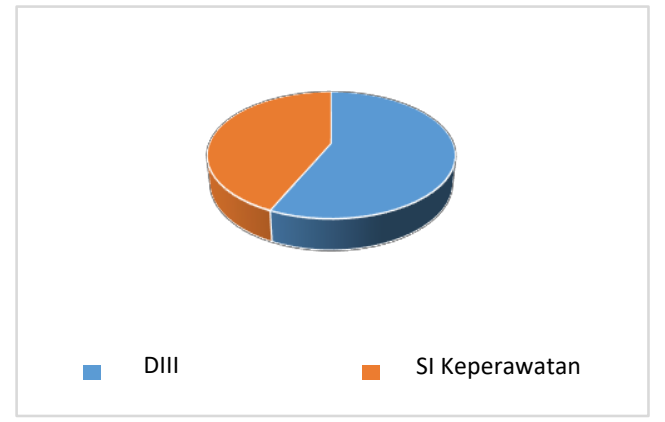

Diagram 6. Karakteristik responden berdasarkan tingkat pengetahuan tentang palliative care pra modul palliative care

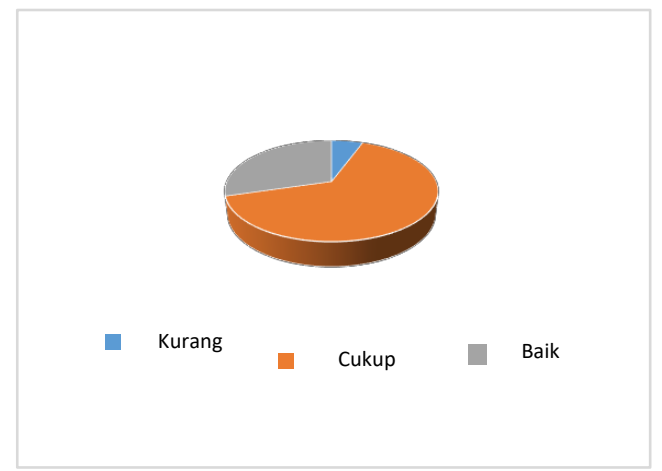

Diagram 7. Karakteristik responden berdasarkan tingkat pengetahuan tentang palliative care post modul palliative care

Pada diagram 5 menunjukkan karakteristik responden berdasarkan tingkat pendidikan sebagian besar responden berpendidikan DIII Keperawatan (57\%). Sedangkan lulusan S1 Keperawatan sebanyak 43\%. Pada diagram 6 menunjukkan karakteristik responden berdasarkan tingkat pengetahuan tentang palliative care pra modul palliative care sebagian besar memiliki pengetahuan yang cukup (55\%), pengetahuan baik (23\%), dan kurang (17\%). Berdasarkan diagram 7 menunjukkan karakteristik responden berdasarkan tingkat pengetahuan tentang palliative care post modul palliative care sebagian besar memiliki pengetahuan yang cukup (65\%), pengetahuan baik (30\%), dan kurang (6\%).

Tabel 1 menunjukkan hasil analisa menggunakan uji rank Wilcoxon diperoleh nilai $Z$ hitung $=-5,599$ dengan $p$ value $0,000<\alpha=0,05$, artinya terdapat perbedaan yang signifikan tingkat pengetahuan perawat sebelum dan setelah diberikan modul dan pelatihan palliative care untuk mengatasi nyeri pada ODHA.

Tabel 1. Uji hipotesis pra dan post pengaruh pemberian modul dan pelatihan modul palliative care terhadap tingkat pengetahuan tentang modul palliative care untuk mengatasi nyeri pada ODHA

\begin{tabular}{|c|c|c|c|c|}
\hline Tkt & Mean & Z & $\mathbf{P}$ & Hasil \\
\hline Pengetahuan & & Hitung & Value & \\
\hline Sebelum & 19,28 & \multirow{2}{*}{5,599} & \multirow{2}{*}{0.000} & Ada \\
\hline Sesudah & 22,88 & & & perbedaan \\
\hline
\end{tabular}


Karakteristik responden berdasarkan jenis kelamin sebagian besar responden berjenis kelamin lakilaki $=55 \%$, sedang perempuan $=45 \%$. Hal ini menggambarkan bahwa terdapat perbedaan proporsi yang signifikan antara perawat laki-laki dan perempuan, yang kemungkinan disebabkan perlu keberanian yang besar untuk merawat pasien ODHA. Seorang perawat profesioanl jika dirinya mampu mengasuh, merawat dan melindungi pasien secara komprehensif dalam melakukan aktifitas keperawatan serta memberikan pelayanan atau asuhan keperawatan pada berbagai jenjang pelayanan keperawatan (Kusnanto, 2004). Hal ini berlaku baik pada perawat perempuan ataupun laki- laki. Pada diagram 2 menunjukkan karakteristik responden berdasarkan usia sebagian besar responden berusia lebih dari 40-50 tahun (60\%). Sedangkan yang berusia 30-40 tahun sebanyak 40\%.

Diagram 3 menunjukkan karakteristik responden berdasarkan tempat kerja, sebagian besar responden berkerja di Puskesmas (66\%). Sedangkan yang bekerja di Rumah Sakit adalah sebesar $34 \%$. Hal ini disebabkan pelayanan pada ODHA khususnya untuk rehabilitatif lebih banyak dilakukan di Puskesmas, dibanding di Rumah Sakit. Hal ini disebabkan pasien ODHA yang melakukan perawatan di Rumah Sakit lebih pada tindakan kuratif saja. Pada diagram 4 menunjukkan karakteristik responden berdasarkan tempat kerja sebagian besar responden telah merawat pasien ODHA > 15 20 tahun (31\%) dan yang paling rendah adalah lama kerja > 10 - 15 tahun 15\%. Lama bekerja pada dasarnya tidak mempengaruhi seorang perawat dalam melakukan palliative care hal ini sesuai dengan Keputusan Depkes RI (2006) bahwa palliative care haruslah dilakukan oleh perawat yang sudah mendapatkan pelatuhan tentang palliative care. Dan ini didukung dengan penelitian yang dilakukan oleh Vobra (2005) perawat yang melakukan palliative care adalah perawat yang mahir di bidangnya.

Pada diagram 5 menunjukkan karakteristik responden berdasarkan tingkat pendidikan sebagian besar responden responden berpendidikan DIII Keperawatan (57\%). Sedangkan lulusan S1 Keperawatan sebanyak 43\%. Pada diagram 6 menunjukkan karakteristik responden berdasarkan tingkat pengetahuan tentang palliative care pra modul palliative care sebagian besar memiliki pengetahuan yang cukup (55\%), pengetahuan baik (23\%), dan kurang (17\%). Hal ini disebabkan sebagian besar rumah sakit atau puskesmas tempat responden bekerja belum pernah dilakukan pelatihan tentang palliative care pada ODHA. Hal ini sesuai dengan Kemenkes (2007) menyatakan bahwa palliative care rumah sakit di Indonesia masih terbatas, demikian juga jumlah perawat yang mempunyai kemampuan untuk memberikan palliative care juga masih terbatas. Hal ini disebabkan keadaan sarana dan prasarana pelayanan palliative care di Indonesia belum merata. Sedangkan pasien pada dasarnya mempunyai hak yang sama untuk mendapatkan pelayanan yang bermutu, komprehensif dan holistik.

Diagram 7 menunjukkan karakteristik responden berdasarkan tingkat pengetahuan tentang palliative care post modul palliative care sebagian besar memiliki pengetahuan yang cukup (65\%), pengetahuan baik (30\%), dan kurang (6\%). Hal ini menunjukkan ada peningkatan pengetahuan pada perawat tentang palliative care untuk mengatasi nyeri pada ODHA, sehingga kualitas hidup ODHA dapat meningkat setelah diberikan modul tentang palliative care pada ODHA. Hal ini sesuai dengan penelitian Adriansen (2005) bahwa pelatihan palliative care memberikan kontribusi yang signifikan pada pengetahuan dan wawasan perawat, kemudian penelitian Choi, Jung, \& Kim (2011) juga mengatakan bahwa rangkaian pendidikan dan pelatihan tentang palliative care efektif untuk meningkatkan pengetahuan perawat mengenai hospis dan palliative care.

Tabel 1 menunjukkan hasil analisa menggunakan uji rank Wilcoxon diperoleh nilai $Z$ hitung = 5,599 dengan $p$ value $0,000<\alpha=0,05$, artinya terdapat perbedaan yang signifikan tingkat pengetahuan perawat sebelum dan setelah diberikan modul dan pelatihan palliative care untuk mengatasi nyeri pada ODHA sehingga hipotesis penelitian" Ada pengaruh Pelatihan dan Modul 
palliative care terhadap tingkat pengetahuan perawat. Nilai rerata tingkat pengetahuan perawat tentang palliative care setelah dilakukan pelatihan lebih besar dari pada sebelum pelatihan $(22,88$ $>19,28$ ). Hasil ini menunjukkan adanya peningkatan pengetahuan perawat tentang palliative care. Hal ini sesuai dengan Universitas Cape Town (UCT) Cape Town, Afrika Selatan yang bekerja sama dengan Divisi Kedokteran Paliatif dari Fakultas Kedokteran Universitas Wales di Cardiff, Inggris Raya (2007) mengakui bahwa pelatihan perawatan paliatif bagi perawat adalah penting, bahwa profesional perawatan kesehatan yang mendapat pelatihan mampu meningkatkan pengetahuan perawatan paliatif, keterampilan, dan sikap mereka.

Hal yang sama diutarakan oleh Arber (1999) dalam jurnal palliative nursing (2015) bahwa perawat yang menyelesaikan modul paliatif meningkatkan pengetahuan mereka tentang perawatan paliatif. Selain itu juga Kementerian kesehatan Republik Indonesia (2007) memutuskan bahwa untuk mengembangkan mutu pelayanan perawatan paliatif perlu pengembangan sumber daya manusia melalui pendidikan dan pelatihan yang berkelanjutan atau Continuing Professional Development untuk meningkatkan pengetahuan tentang palliative care baik jumlah, jenis, dan kualitas pelayanan.

\section{SIMPULAN DAN SARAN}

Perawat memiliki pengetahuan tentang pallative care untuk menurunkan nyeri pada ODHA kategori cukup (65\%), pengetahuan baik (30\%) dan kurang (6\%). Perawat setelah diberikan pelatihan dan modul tentang palliative care untuk menurunkan nyeri pada ODHA sebagian besar memiliki pengetahuan yang cukup (65\%), pengetahuan baik (30\%) dan kurang (6\%). Ada perbedaan yang signifikan tingkat pengetahuan perawat sebelum dan setelah diberikan modul dan pelatihan palliative care untuk mengatasi nyeri pada ODHA dengan nilai rerata tingkat pengetahuan perawat tentang palliative care setelah dilakukan pelatihan lebih besar dari pada sebelum pelatihan $(22,88>19,28)$. Perawat dapat selalu memperbarui keilmuan melalui kegiatan ilmiah dan pelatihan, sehingga dapat meningkatkan kualitas layanan keperawatan terutama dalam menerapkan palliative care pada pasien.

\section{DAFTAR PUSTAKA}

Andriansen (2005). Effect of Postqualification Course In Palliative Care. The netgerland. Departement Of Nursing. University of Proffesional Education.

Gwyther, L., \&Rawlinson, F. (2007). Palliative Medicine Teaching Program at the. Journal of Pain and Symptom Management, 33(5).

Kassa, H., Murugan, R., Zewdu, F., Hailu, M \& Woldeyohannes, D. (2014). Assessment of knowledge, attitude and practiceand associated factors towards palliative careamong nurses working in selected hospitals,Addis Ababa, Ethiopia. BMC Palliative Care, 13(6): 1-11.

Kementerian Kesehatan RI. (2015). Panduan Asuhan Keperawatan Paliatif di Rumah. http://perpustakaan.depkes.go.id:8180/ha ndle/123456789/2226.

Komisi Penanggulangan Aids. (2016). Data Kasus HIV-Aids di Jawa Tengah, https://www.aidsjateng.or.id/.

Nursalam. (2007). Asuhan keperawatan pasien terinfeksi HIV/Aids. Jakarta: Salemba Medika.

Nursalam. (2005). The Effect of PAKAR on the increase of CD4 cell account patient with HIV infection, journal.unair.ac.id/FMI@research-article:the-effect-of-nursing-care-approach-model Palliative Care Quality Network. (2017). https://www.pcqn.org/. 
Ross. M. M., McDonald. B., \& McGumness. J. (1996). The palliative care quiz for nursing(PCQN):the development of an instrument to measure nurses'k nowledge of palliative care. Jounal of Advanced Nursing,23,.p. 126-137

RI, K. K. (2007). Keputusan Menteri Kesehatan Republik Indonesia Nomor:812/Menkes/Sk/Vii/2007

Soewandojo, Eddy., Suharto., Usman, Hadi., dan Nasronudin. (2007). Buku Ajar Ilmu Penyakit Dalam. Surabaya: Airlangga University Press.

Willy F.Maramis, Albert A.Maramis. (2009). Catatan Ilmu Kedokteran Jiwa Edisi. 2. Surabaya: Airlangga University Press

Wulandari, Fitriana. (2012). Hubungan Tingkat Pengetahuan Perawat te ntang Perawatan Paliatif dengan Sikap Terhadap Penatalaksanaan Pasien dalam Perawatan Paliatif di RS Dr. Moewardi Surakarta. Naskah Publikasi. Fakultas Ilmu Kesehatan. Universitas MuhammadiyahSurakartahttp://v2.eprint s.ums.ac.id/archive/21972/. 